\title{
A novel noncoding FKRP mutation in early onset limb-girdle muscular dystrophy
}

Ezgi Saylam, MD, Steven A. Moore, MD, PhD, Akilandeswari Aravindhan, MBBS, Heather Marton, PhD, Peter L. Nagy, MD, PhD, Murat Gokden, MD, Mary O. Cox, BS, Vikki Stefans, MD, and Aravindhan Veerapandiyan, MD
Correspondence

Dr. Veerapandiyan

aveerapandiyan@uams.edu

Neurol Genet 2020;6:e388. doi:10.1212/NXG.0000000000000388

Limb-girdle muscular dystrophy 2I (LGMD2I, LGMD R9) (OMIM: muscular dystrophydystroglycanopathy [limb-girdle], type $\mathrm{C}, 5)$ is an autosomal recessive disorder caused by mutations in the fukutin-related protein (FKRP) gene. ${ }^{1}$ The phenotypic spectrum associated with FKRP is heterogeneous; the most severe phenotype, Walker-Warburg-like syndrome, is characterized by congenital hypotonia, progressive muscle weakness and atrophy, ocular and brain malformations, severe motor developmental delay, and profound intellectual disability. Milder phenotypes include the onset of disease from infancy to adulthood and variable clinical course including asymptomatic elevated serum creatinine kinase (CK), early onset rapidly progressive course with loss of ambulation in teenage years, late onset with slow progression, and primary cardiomyopathy with minimal skeletal muscle weakness. ${ }^{1,2}$ LGMD2I is typically characterized by proximal muscle weakness, calf hypertrophy, hypotonia, elevated CK level, normal cognition, and no structural brain abnormalities. Dilated cardiomyopathy and respiratory muscle weakness can be seen. ${ }^{1}$ Mutations in the FKRP gene reduce specific O-mannose-linked glycosylation of alphadystroglycan, leading to the instability of the linkage between the dystrophin-glycoprotein complex and laminin alpha 2 in the basement membrane of skeletal muscle. ${ }^{3}$ The most common FKRP mutation seen in LGMD2I is c.826C $>$ A (p.Leu276Ile). Patients who are homozygous for this mutation typically have a milder phenotype, whereas compound heterozygotes have a relatively severe clinical course. In patients heterozygous for c.826C $>\mathrm{A}$, clinical severity may correspond best to the mutation in the second allele. ${ }^{1,4}$ We describe a 9-year-old boy with LGMD2I who has the c.826C $>\mathrm{A}$ mutation in FKRP on 1 allele and a novel variant on the second allele.

Our patient presented with a 3-year history of slowly progressive muscle weakness. He was born at term after a normal pregnancy. His growth and early developmental milestones were normal. Initial symptoms included leg pain ${ }^{5}$ and toe walking that was noticed around 6 years of age. Over the next 3 years, he exhibited difficulties with running, jumping, rising from the floor, and climbing stairs. His medical, family, and neurodevelopmental history was otherwise unremarkable. Neurologic examination revealed proximal limb-girdle weakness, truncal weakness, hypotonia, positive Gowers sign, and waddling gait. Musculoskeletal examination showed calf hypertrophy and tight heel cords. The remainder of the examination was normal. Serum CK level was $9701 \mathrm{U} / \mathrm{L}$. EMG of the lower extremity muscles suggested a myopathic process. The initial next generation sequencing (Invitae comprehensive muscular dystrophy panel of 48 genes) revealed the known pathogenic variant, c.826C >A (p.Leu276Ile), in FKRP exon 4. This panel covered coding exons and only \pm 10 base pairs of adjacent intronic sequence of each gene, and variants outside these would not be detected. Subsequently, trio whole exome sequencing confirmed the presence of this variant inherited from his father and identified a novel variant in FKRP, c.-253+4A $>\mathrm{G}$ (Chr19:47249351 [GRCh37] ENST00000391909.7) in intron 1, inherited from his mother. No variants were identified in the other genes associated with dystroglycanopathies. ${ }^{6}$ His parents are asymptomatic. $\mathrm{He}$

From the Department of Pediatrics (E.S., A.A., A.V.), Arkansas Children's Hospital, University of Arkansas for Medical Sciences, Little Rock; MNG Laboratories (H.M., P.N.), Atlanta, GA; Department of Pathology (S.A.M., M.O.C.), University of lowa; Department of Pathology (M.G.), University of Arkansas for Medical Sciences, Little Rock; Departments of Pediatrics and Physical Medicine and Rehabilitation (V.S.), Arkansas Children's Hospital, University of Arkansas for Medical Sciences, Little Rock.

Go to Neurology.org/NG for full disclosures. Funding information is provided at the end of the article.

The Article Processing Charge was funded by the authors.

This is an open access article distributed under the terms of the Creative Commons Attribution-NonCommercial-NoDerivatives License 4.0 (CC BY-NC-ND), which permits downloading and sharing the work provided it is properly cited. The work cannot be changed in any way or used commercially without permission from the journal. 
Figure Muscle biopsy (A-I): many histopathologic changes characteristic of a muscular dystrophy are present in the patient's quadriceps biopsy: myonecrosis and regeneration, atrophy and hypertrophy, and endomysial fibrosis (A and B)

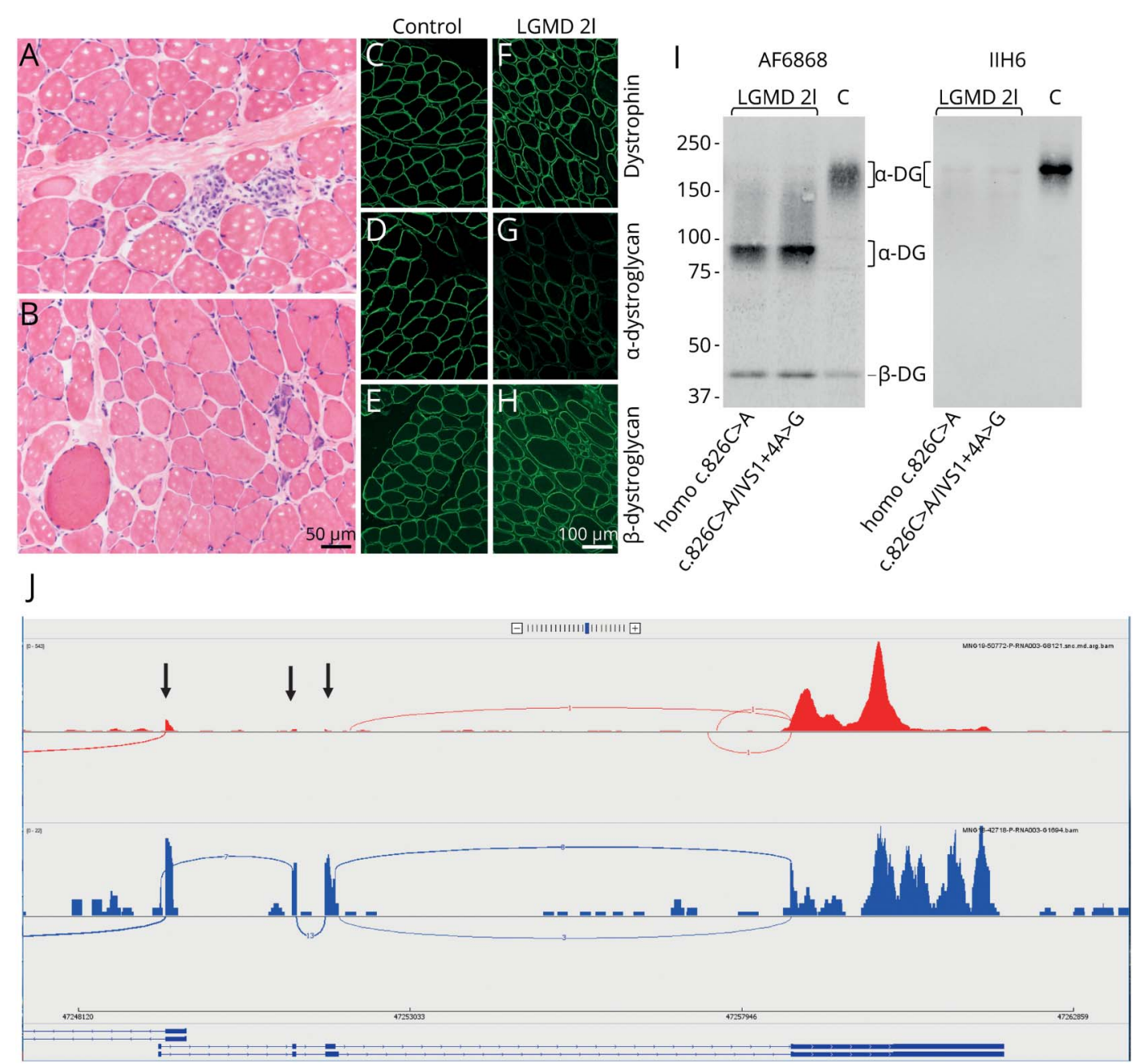

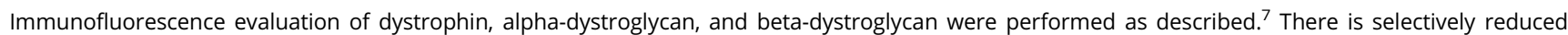
staining for alpha-dystroglycan using a matriglycan-specific antibody, IIH6 (C-H). The mosaic pattern of reduced to absent immunostaining is characteristic of milder dystroglycanopathy phenotypes $(\mathrm{G})$. Western blotting of pooled muscle biopsy cryosections followed the methods described previously. ${ }^{7}$ Blotting with a core peptide antibody, AF6868, shows that our patient has reduced molecular weight alpha-dystroglycan that is very similar to a patient with homozygous c.826C $>$ A FKRP mutations. Normal control muscle is designated as " $\mathrm{C}$ ". Almost no fully glycosylated alpha-dystroglycan is detected by IIH6 in either our patient or the patient with homozygous C.826C >A FKRP mutations (I). RNA sequencing (J): Sashimi plot of FKRP expression in muscle of our patient (red) and control (blue). Expression of the 3 non-coding exons of FKRP is absent in the patient compared with control (arrows). RNA sequencing examination revealed 0-12 reads covering the untranslated exons of the FKRP gene and 31-543 reads covering the translated exons in our patient. In comparison, $2-15$ reads covering the untranslated exons of the FKRP gene and a similar number of reads covering the translated exons ( $0-22$ reads) were seen in control sample. Junction reads spanning the non-coding exons are present in the control sample and are essentially absent $(\leq 1)$ in the patient. This indicates a disruption in the splicing between exons 1, 2,3, and 4 in the patient which is consistent with the c.-253+4A>G variant affecting normal splicing. FKRP $=$ fukutin-related protein; LGMD $=$ limb-girdle muscular dystrophy.

then underwent muscle biopsy that showed a dystrophic process: prominent fiber size variation, myonecrosis, regeneration, and fibers with increased internal nuclei sometimes associated with fiber splitting. No neurogenic or inflammatory changes were noted. Immunostaining revealed a mosaic pattern of reduced to absent staining for alphadystroglycan using the matriglycan-specific antibody IIH6 (figure). Immunostaining for dystrophin, beta-dystroglycan, and spectrin were normal. Western blotting confirmed the glycosylation abnormality by showing reduced molecular weight of alpha-dystroglycan and near absence of binding to IIH6. Echocardiogram was normal.
The Leu276Ile variant is the most common FKRP pathogenic variant. ${ }^{1}$ The second variant found in our patient, $c$.$253+4 A>G$, has not been reported previously. Because this variant destroys the canonical splice donor site in intron 1 , it is expected to cause abnormal gene splicing. Several in silico analyses (MutationTaster, NNSplice, and NetGene2) predict this variant is likely to affect splicing. Indeed, RNA sequencing in our patient confirmed that the c.-253+4A>G variant disrupts normal splicing (figure). Thus, based on the clinical features, compound heterozygosity with a common FKRP mutation in 1 allele, reduced immunostaining for alpha-dystroglycan, abnormal glycosylation by western blot, 
and abnormal splicing caused by the second variant, we speculate that the novel FKRP variant in second allele is associated with the LGMD2I phenotype in our patient.

We suggest that the variant c. $-253+4 A>G$ can be added to the repertoire of variants in FKRP associated with LGMD2I. Whole exome sequencing may be needed in patients with strong clinical suspicion for etiologic delineation in the event of ambiguous results on widely available next generation sequencing panel testing. Furthermore, this report emphasizes the importance of muscle biopsy for establishing a precise diagnosis when genetic testing results are inconclusive.

\section{Acknowledgment}

The authors acknowledge Ms. Terese Nelson who performed the histology and immunostaining and Mr. Joel Carl for assembling the figure

\section{Study funding}

Muscle biopsy evaluation was supported by the Iowa Wellstone Muscular Dystrophy Cooperative Research Center, NIH grant U54, NS053672 (SAM).

\section{Disclosure}

Disclosures available: Neurology.org/NG.

\section{Publication history}

Received by Neurology: Genetics July 23, 2019. Accepted in final form November 14, 2019.

Appendix Authors

\begin{tabular}{llll}
\hline Name & Location & Role & Contribution \\
\hline Ezgi Saylam, MD & $\begin{array}{l}\text { University of } \\
\text { Arkansas for } \\
\text { Medical } \\
\text { Sciences, Little } \\
\text { Rock }\end{array}$ & Author & $\begin{array}{l}\text { Data collection, } \\
\text { drafting the } \\
\text { manuscript }\end{array}$ \\
\hline $\begin{array}{lll}\text { Steven A. } \\
\text { Moore, MD, PhD }\end{array}$ & $\begin{array}{l}\text { University of } \\
\text { lowa }\end{array}$ & Author & $\begin{array}{l}\text { Revising the } \\
\text { manuscript, muscle } \\
\text { biopsy interpretation, } \\
\text { western blot, } \\
\text { acquisition and } \\
\text { organization of } \\
\text { figures }\end{array}$ \\
& & & \\
& & & \\
& & & \\
\hline
\end{tabular}

Appendix (continued)

\begin{tabular}{|c|c|c|c|}
\hline Name & Location & Role & Contribution \\
\hline $\begin{array}{l}\text { Akilandeswari } \\
\text { Aravindhan, } \\
\text { MBBS }\end{array}$ & $\begin{array}{l}\text { University of } \\
\text { Arkansas for } \\
\text { Medical } \\
\text { Sciences, Little } \\
\text { Rock }\end{array}$ & Author & $\begin{array}{l}\text { Data collection, } \\
\text { drafting the } \\
\text { manuscript, revising } \\
\text { the manuscript }\end{array}$ \\
\hline $\begin{array}{l}\text { Heather } \\
\text { Marton, PhD }\end{array}$ & $\begin{array}{l}\text { MNG } \\
\text { Laboratories, } \\
\text { Atlanta, GA }\end{array}$ & Author & $\begin{array}{l}\text { RNA sequencing, } \\
\text { acquisition of the RNA } \\
\text { sequencing data, } \\
\text { organization of } \\
\text { figures, revising the } \\
\text { manuscript }\end{array}$ \\
\hline $\begin{array}{l}\text { Peter Nagy, MD, } \\
\text { PhD }\end{array}$ & $\begin{array}{l}\text { MNG } \\
\text { Laboratories, } \\
\text { Atlanta, GA }\end{array}$ & Author & $\begin{array}{l}\text { RNA sequencing, } \\
\text { acquisition of the RNA } \\
\text { sequencing data, } \\
\text { organization of } \\
\text { figures, revising the } \\
\text { manuscript }\end{array}$ \\
\hline $\begin{array}{l}\text { Murat Gokden, } \\
\text { MD }\end{array}$ & $\begin{array}{l}\text { University of } \\
\text { Arkansas for } \\
\text { Medical } \\
\text { Sciences, Little } \\
\text { Rock }\end{array}$ & Author & $\begin{array}{l}\text { Revising the } \\
\text { manuscript, muscle } \\
\text { biopsy interpretation, } \\
\text { acquisition and } \\
\text { organization of figures }\end{array}$ \\
\hline Mary O. Cox, BS & $\begin{array}{l}\text { University of } \\
\text { lowa, lowa City }\end{array}$ & Author & $\begin{array}{l}\text { Acquisition of western } \\
\text { blot data }\end{array}$ \\
\hline $\begin{array}{l}\text { Vikki Stefans, } \\
\text { MD }\end{array}$ & $\begin{array}{l}\text { University of } \\
\text { Arkansas for } \\
\text { Medical } \\
\text { Sciences, Little } \\
\text { Rock }\end{array}$ & Author & $\begin{array}{l}\text { Cared for the patient, } \\
\text { revising the } \\
\text { manuscript }\end{array}$ \\
\hline $\begin{array}{l}\text { Aravindhan } \\
\text { Veerapandiyan, } \\
\text { MD }\end{array}$ & $\begin{array}{l}\text { University of } \\
\text { Arkansas for } \\
\text { Medical } \\
\text { Sciences, Little } \\
\text { Rock }\end{array}$ & Author & $\begin{array}{l}\text { Cared for the patient, } \\
\text { study concept, } \\
\text { drafting and revising } \\
\text { the manuscript }\end{array}$ \\
\hline
\end{tabular}

\section{References}

1. Amato AA. Other limb-girdle muscular dystrophies. Handb Clin Neurol 2011;101:119-124.

2. Schwartz M, Hertz JM, Sveen ML, Vissing J. LGMD2I presenting with a characteristic Duchenne or Becker muscular dystrophy phenotype. Neurology 2005;64:1635-1637.

3. Yoshida-Moriguchi T, Campbell KP. Matriglycan: a novel polysaccharide that links dystroglycan to the basement membrane. Glycobiology 2015;25:702-713.

4. Wang DN, Wang ZQ, Chen YQ, Xu GR, Lin MT, Wang N. Limb-girdle muscular dystrophy type 2I: two Chinese families and a review in Asian patients. Int J Neurosci 2018;128:199-207.

5. Mathews $\mathrm{KD}$, Stephan $\mathrm{CM}$, Laubenthal $\mathrm{K}$, et al. Myoglobinuria and muscle pain are common in patients with limb-girdle muscular dystrophy 2I. Neurology 2011;76:194-195.

6. Nigro V, Savarese M. Genetic basis of limb-girdle muscular dystrophies: the 2014 update. Acta Myol 2014;33:1-12.

7. Lee AJ, Jones KA, Butterfield RJ, et al. Clinical, genetic, and pathologic characterization of FKRP Mexican founder mutation c.1387A>G. Neurol Genet 2019;5:e315. doi: $10.1212 /$ NXG.0000000000000315. 


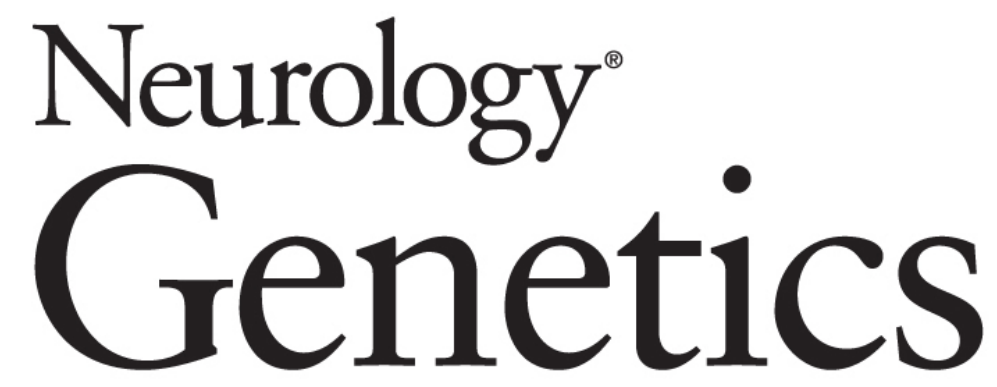

A novel noncoding FKRP mutation in early onset limb-girdle muscular dystrophy Ezgi Saylam, Steven A. Moore, Akilandeswari Aravindhan, et al. Neurol Genet 2020;6;

DOI 10.1212/NXG.0000000000000388

This information is current as of December 26, 2019

Neurol Genet is an official journal of the American Academy of Neurology. Published since April 2015, it is an open-access, online-only, continuous publication journal. Copyright Copyright @ 2019 The Author(s). Published by Wolters Kluwer Health, Inc. on behalf of the American Academy of Neurology.. All rights reserved. Online ISSN: 2376-7839.

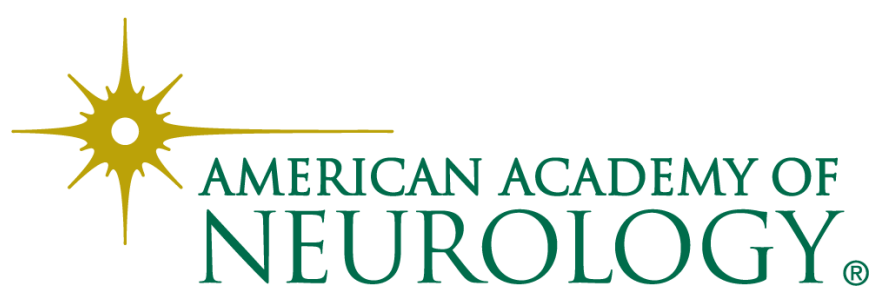




\section{Updated Information \& Services}

References

Subspecialty Collections

Permissions \& Licensing

\section{Reprints}

including high resolution figures, can be found at: http://ng.neurology.org/content/6/1/e388.full.html

This article cites 7 articles, 1 of which you can access for free at: http://ng.neurology.org/content/6/1/e388.full.html\#\#ref-list-1

This article, along with others on similar topics, appears in the following collection(s):

\section{All Genetics}

http://ng.neurology.org//cgi/collection/all_genetics

\section{All Neuromuscular Disease}

http://ng.neurology.org//cgi/collection/all_neuromuscular_disease All Pediatric

http://ng.neurology.org//cgi/collection/all_pediatric

EMG

http://ng.neurology.org//cgi/collection/emg

Muscle disease

http://ng.neurology.org//cgi/collection/muscle_disease

Information about reproducing this article in parts (figures,tables) or in its entirety can be found online at:

http://ng.neurology.org/misc/about.xhtml\#permissions

Information about ordering reprints can be found online:

http://ng.neurology.org/misc/addir.xhtml\#reprintsus

Neurol Genet is an official journal of the American Academy of Neurology. Published since April 2015, it is an open-access, online-only, continuous publication journal. Copyright Copyright $\odot 2019$ The Author(s). Published by Wolters Kluwer Health, Inc. on behalf of the American Academy of Neurology.. All rights reserved. Online ISSN: 2376-7839.

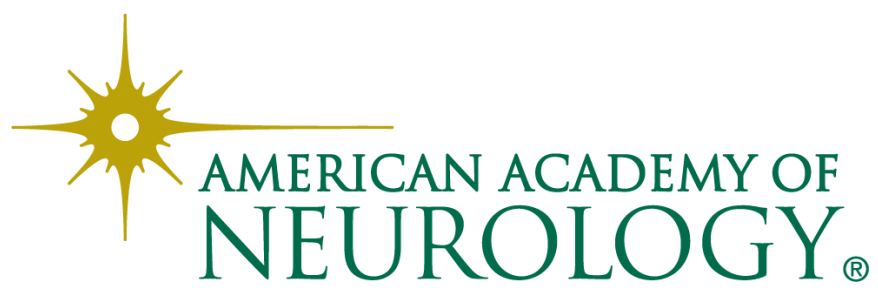

